\title{
Antimicrobial Effect of 7-O-Butylnaringenin, a Novel Flavonoid, and Various Natural Flavonoids against Helicobacter pylori Strains
}

\section{Sun Hee Moon ${ }^{1,2}$, Jae Hoon Lee ${ }^{2}$, Kee-Tae Kim ${ }^{3}$, Yong-Sun Park ${ }^{2,3,4}$, Seung-Yeol Nah ${ }^{2,3,5}$, Dong Uk Ahn ${ }^{1,6}$ and Hyun-Dong Paik ${ }^{2,3, *}$}

1 Department of Animal Science, Iowa State University, Ames 50011, USA;

E-Mails: smoon@iastate.edu (S.H.M.); duahn@iastate.edu (D.U.A.)

Division of Animal Life Science, Konkuk University, Seoul 143-701, Korea;

E-Mails: jokko77@naver.com (J.H.L.); parkyong@konkuk.ac.kr (Y.-S.P.); synah@konkuk.ac.kr (S.-Y.N.)

3 Bio/Molecular Informatics Center, Konkuk University, Seoul 143-701, Korea;

E-Mail: richard44@hanmail.net

Department of Chemistry, Konkuk University, Seoul 143-701, Korea

5 Department of Physiology, College of Veterinary Medicine, Konkuk University, Seoul 143-701, Korea

6 Department of Animal Science and Technology, Sunchon National University, Sunchon 540-742, Korea

* Author to whom correspondence should be addressed; E-Mail: hdpaik@konkuk.ac.kr; Tel.: +82-2-2049-6011; Fax: +82-2-455-3082.

Received: 5 August 2013; in revised form: 16 October 2013 / Accepted: 21 October 2013 / Published: 28 October 2013

\begin{abstract}
The antimicrobial effect of a novel flavonoid (7-O-butylnaringenin) on Helicobacter pylori 26695, 51, and SS1 strains and its inhibitory effect on the urease activity of the strains were evaluated and compared with those of several natural flavonoids. First, various flavonoids were screened for antimicrobial activities using the paper disc diffusion method. Hesperetin and naringenin showed the strongest antimicrobial effects among the natural flavonoids tested, and thus hesperetin and naringenin were selected for comparison with 7-O-butylnaringenin. The antimicrobial effect of 7-O-butylnaringenin was greater than that of the hesperetin and naringenin. H. pylori 51 was more sensitive to 7-O-butylnaringenin ( $2 \log$ reduction of colony forming units, $p<0.05)$ than the other two strains at $200 \mu \mathrm{M}$. 7-O-Butylnaringenin also showed the
\end{abstract}


highest inhibitory effect against urease activity of $H$. pylori. Morphological changes of H. pylori 26695 treated with these flavonoids indicated that both hesperetin and 7-O-butylnaringenin at $200 \mu \mathrm{M}$ damaged the cell membranes.

Keywords: flavonoid; Helicobacter pylori; 7-O-butylnaringenin; hesperitin; antimicrobial effect; urease activity

\section{Introduction}

Helicobacter pylori is a micro-aerophilic, Gram-negative, spiral-shaped flagellated bacterium [1]. This microorganism lives in the stomach and duodenum and is known to be one of the most common chronic bacterial pathogens of humans. $H$. pylori is associated with several diseases, including chronic gastritis, peptic ulcers, and gastric mucosa associated lymphoid tissue lymphoma [2-5].

$H$. pylori is resistant to stomach acid because it is protected by the mucous cells and its urease activity [2]. Urease, which is the most characteristic feature of $H$. pylori, catalyzes the hydrolysis of urea to produce ammonia and $\mathrm{CO}_{2}$, and protects the bacteria from the acidic environment of the stomach [6,7]. Ammonia itself may cause tissue injury or be toxic to intercellular junctions [8]. However, ammonia generated by the urease buffers gastric acid, and thus is also important for the colonization of the bacteria in the stomach. The urease of $H$. pylori has been described as a highly active enzyme that may be associated with virulence [9] and is considered as a constitutive and permanently active enzyme [10]. The urease in $H$. pylori is a high-molecular weight enzyme that has a high affinity to urea and rapidly hydrolyzes it, but is highly sensitive to urease inhibitors. To treat the patients with gastro-duodenal diseases by $H$. pylori, therefore, inhibiting the infection, growth, and urease activity of $H$. pylori is important. Antimicrobial drugs have been used to treat $H$. pylori infections in recent years, and the successful eradication of this bacterium has been demonstrated to prevent the relapse of duodenal and gastric ulcers [10-12].

Many naturally occurring compounds found in dietary and medicinal plants, herbs and fruit extracts have been shown to possess antimicrobial activities [13-16]. Flavonoids are natural compounds ubiquitous in green plant cells [17]. Flavonoids appear to have antimicrobial, antioxidative, anti-inflammatory and anti-carcinogenic effects, and have played major roles in successful medical treatments since ancient times and their use has continued to these days [18-20]. There have been various studies on the functional effects of flavonoids with regard to their use by the health food and pharmaceutical industries [21-23]. In particular, it has been shown that certain flavonoids have antimicrobial effects against $H$. pylori $[13,24,25]$. Although the Minimum Inhibitory Concentration (MIC) of some flavonoids against the growth of $H$. pylori has been determined, the nature of the inhibitory effects has not been sufficiently studied [14]. In addition, a new chemically-derived flavonoid has recently been evaluated for its functional activities as a medicinal compound [19]. With this approach, the protective mechanism of some popularly used flavonoids (naringenin and hesperetin), and 7-O-butylnaringenin, a new modified flavonoid from naringenin, on the growth as well as the urease activity of $H$. pylori was studied. 


\section{Experimental Section}

\subsection{Bacterial Strains}

H. pylori 26695, 51, and SS1 were purchased from the $H$. pylori Korean-Type Culture Collection (HpKTCC, Jinju, Korea). The strains were activated in brucella agar (Difco Laboratories, Detroit, MI, USA) plates supplemented with $5 \%(\mathrm{v} / \mathrm{v})$ horse serum and was cultured under micro-aerophilic conditions ( $10 \% \mathrm{CO}_{2}$ atmosphere) for 3 days. For these studies, the strains were then inoculated in brucella broth supplemented with $5 \%$ horse serum and were cultured for 1 day at $37^{\circ} \mathrm{C}$ before use.

\subsection{Flavonoids}

Nine different flavonoids were used for comparison in this study; kaempferol, and quercetin as flavonols, apigenin, luteolin, and 5,4'-dihydroxy-7-methoxyflavone (genkwanin) as flavones, and naringenin, hesperetin, and hesperidin as flavanones [26] (Figure 1).

Figure 1. Chemical structures of flavonoids used in this study. (A) kaempferol, (B) quercetin, (C) apigenin, (D) naringenin, (E) luteolin, (F) hesperetin, (G) hesperidin, (H) genkwanin, and (I) 7-O-butylnaringenin.<smiles>O=c1c(O)c(-c2ccc(O)cc2)oc2cc(O)cc(O)c12</smiles><smiles>O=c1c(O)c(-c2ccc(O)c(O)c2)oc2cc(O)cc(O)c12</smiles><smiles>O=c1cc(-c2ccc(O)cc2)oc2cc(O)cc(O)c12</smiles><smiles>O=C1CC(c2ccc(O)cc2)Oc2cc(O)cc(O)c21</smiles>

(E)<smiles>O=c1cc(-c2ccc(O)c(O)c2)oc2cc(O)cc(O)c12</smiles>

(F)<smiles>COc1ccc(C2CC(=O)c3c(O)cc(O)cc3O2)cc1O</smiles>

(G)<smiles>COc1ccc(C2Cc3cc(O)cc(O)c3C(O)C2)cc1O</smiles>

(H)<smiles>CCCOc1cc(O)c2c(c1)OC(c1ccc(O)cc1)CC2=O</smiles>

All flavonoids were purchased from Sigma Chemical Co. (St. Louis, MO, USA). 7-O-Butylnaringenin was supplied by the Chemistry Department in Konkuk University. 7-O-Butylnaringenin solution was prepared by mixing and stirring naringenin (500 $\mathrm{mg}, 1.84 \mathrm{mM})$, butyl bromide (1.5 equiv.) and $\mathrm{K}_{2} \mathrm{CO}_{3}$ (1.0 equiv.) in dimethylformamide (DMF, $10 \mathrm{~mL}$ ) for $12 \mathrm{~h}$ at $25^{\circ} \mathrm{C}$. The mixture was quenched by adding saturated aqueous $\mathrm{NH}_{4} \mathrm{Cl}$ and then extracted with ethyl acetate. 
The extracts were then dried over anhydrous $\mathrm{MgSO}_{4}$. After evaporation, the resulting crude product was purified using a flash column chromatography, which produced a colorless oil in 35\% yield [19].

\subsection{Screening by Paper Disc Diffusion Method}

The paper disc diffusion method was used as a screening test for the antibacterial activity of flavonoids [2]. H. pylori was incubated as described above. Fourty microliters of flavonoid sample were applied to a paper disc ( $8 \mathrm{~mm}$ in diameter) and the concentrations of flavonoids were $2.5,5,10$, and $20 \mathrm{mM}$ in dimethylsulfoxide (DMSO), respectively. The DMSO was removed by drying at $20{ }^{\circ} \mathrm{C}$ for $10 \mathrm{~min}$, and the paper discs were placed on brucella agar plates supplemented with $5 \%$ horse serum inoculated with $2.0 \times 10^{7} \mathrm{CFU} / \mathrm{mL}$ of each $\mathrm{H}$. pylori strain. The zone of inhibition was determined after incubating the plates at $37{ }^{\circ} \mathrm{C}$ for 3 days under $10 \% \mathrm{CO}_{2}$ incubator (MCO-18AIC; Sanyo, Oizumi-Machi, Japan).

\subsection{Assay of Antimicrobial Effects on H. pylori}

The initial cell numbers of $H$. pylori strains were adjusted to $2.0 \times 10^{5} \mathrm{CFU} / \mathrm{mL}$ in broth. Four milliliters of brucella supplemented with $5 \%(\mathrm{v} / \mathrm{v})$ horse serum, $1 \mathrm{~mL}$ of culture broth, and $50 \mu \mathrm{L}$ of flavonoid solution were added to each well and cultured at $37{ }^{\circ} \mathrm{C}$ under $10 \% \mathrm{CO}_{2}$ atmosphere. The concentration of flavonoid was adjusted to 100 and $200 \mu \mathrm{M}$ in total broth per well. For the blank and control, $50 \mu \mathrm{L}$ of distilled water and DMSO were added instead of flavonoid solutions, respectively. After $24 \mathrm{~h}$ incubation, culture samples including the blank and control, were serially diluted in $0.1 \%$ peptone water and spread on brucella agar supplemented with $5 \%(\mathrm{v} / \mathrm{v})$ horse serum. Plates were incubated for 3 days at $37{ }^{\circ} \mathrm{C}$ under $10 \% \mathrm{CO}_{2}$ atmosphere [21]. The effect of flavonoids on the H. pylori strains was determined using the standard cell counting method.

\subsection{Flavonoid Inhibition of Urease in $\mathrm{H}$. pylori}

Urease activity was measured by the method of Malekzadeh et al. [27] and Mobley et al. [28]. One thousand eight hundred microliters of urea broth (urea $20 \mathrm{~g}, \mathrm{NaCl} 5 \mathrm{~g}, \mathrm{KH}_{2} \mathrm{PO}_{4} 2 \mathrm{~g}$, peptone $1 \mathrm{~g}$, glucose $1 \mathrm{~g}$, and phenol red $0.012 \mathrm{~g}$ per L solution), $200 \mu \mathrm{L}$ of the cultured broth, and $20 \mu \mathrm{L}$ of the flavonoid solutions were mixed in a test tube. The initial cell number of $H$. pylori was adjusted to $2.0 \times 10^{5} \mathrm{CFU} / \mathrm{mL}$ reaction mixture, and the concentration of flavonoid was adjusted to $200 \mu \mathrm{M}$ for each reaction mixture. For control, $20 \mu \mathrm{L}$ of DMSO instead of flavonoid solution was added. After $3 \mathrm{~h}$ of incubation at $37^{\circ} \mathrm{C}$, the changes of optical density (pink red color) in urea broth by the ammonia produced were measured at $560 \mathrm{~nm}$ with a spectrophotometer (EL311; Bio-Tek Instruments Inc., Seoul, Korea).

\subsection{Preparation of H. pylori for Scanning Electron Microscopy (SEM)}

Bacterial cells were prepared for SEM examination using the methods of Tsugawa et al. [29]. Cell broth was cultured in brucella broth supplemented with $5 \%$ horse serum for $24 \mathrm{~h}$ at $37{ }^{\circ} \mathrm{C}$ under $10 \% \mathrm{CO}_{2}$ and were treated with $200 \mu \mathrm{M}$ of hesperetin, naringenin, or 7-O-butylnaringenin. The cells were harvested by centrifugation at $10,000 \times \mathrm{g}$ for $10 \mathrm{~min}$ and fixed overnight with $25 \%(\mathrm{v} / \mathrm{v})$ 
glutaraldehyde at $4{ }^{\circ} \mathrm{C}$. The cells were then washed with $0.1 \mathrm{M}$ phosphate buffer $(\mathrm{pH} 7.0)$ three times and dehydrated by washing with ethanol. The ethanol concentration for washing was gradually increased from $10 \%$ to $100 \%$ in a sequential manner. The dehydrated specimens were treated with ion-spotter-coating at $7 \mathrm{~V}$ and $15 \mathrm{~mA}$ in a vacuum evaporator (E-1010, Hitachi Science System Ltd., Hitachinaka, Japan) and subjected to SEM (S-3000N, Hitachi Science System Ltd.).

\subsection{Statistical Analysis}

All results are presented as mean \pm standard error (SE), and statistical analysis was performed using the SPSS (Chicago, IL, USA) package for Windows (Ver. 18.0). The mean values were compared using one-way analysis of variance (ANOVA) followed by Duncan's multiple range tests with a significance defined at $p<0.05$. Correlations were determined using Pearson's correlation coefficient.

\section{Results and Discussion}

\subsection{Screening by Paper Disc Diffusion Method}

Quercetin, kaempferol, naringenin, and hesperetin had stronger antimicrobial effects than the other flavonoids tested. The antimicrobial effects of naringenin and hesperetin were greater than those of other flavonoids used in this study. Apigenin, hesperidin, and genkwanin had no effects, even at $20 \mathrm{mM}$, against all $H$. pylori strains studied (Table 1).

Table 1. Zone of growth inhibition of $H$. pylori 26695, 51, and SS1.

\begin{tabular}{|c|c|c|c|c|}
\hline Flavonoid & Conc. (mM) & H. pylori 26695 & H. pylori 51 & H. pylori SS1 \\
\hline \multirow{4}{*}{ Kaempferol } & 2.5 & - & - & - \\
\hline & 5 & ++ & - & + \\
\hline & 10 & ++ & + & + \\
\hline & 20 & ++ & + & ++ \\
\hline \multirow{4}{*}{ Quercetin } & 2.5 & - & - & - \\
\hline & 5 & - & - & - \\
\hline & 10 & - & - & + \\
\hline & 20 & + & - & + \\
\hline \multirow{4}{*}{ Apigenin } & 2.5 & - & - & - \\
\hline & 5 & - & - & - \\
\hline & 10 & - & - & - \\
\hline & 20 & - & - & - \\
\hline \multirow{4}{*}{ Naringenin } & 2.5 & - & - & - \\
\hline & 5 & +++ & +++ & +++ \\
\hline & 10 & +++ & +++ & +++ \\
\hline & 20 & +++ & +++ & +++ \\
\hline \multirow{4}{*}{ Luteolin } & 2.5 & - & - & - \\
\hline & 5 & + & + & - \\
\hline & 10 & ++ & ++ & + \\
\hline & 20 & ++ & ++ & + \\
\hline
\end{tabular}


Table 1. Cont.

\begin{tabular}{ccccc}
\hline Flavonoid & Conc. (mM) & H. pylori 26695 & H. pylori 51 & H. pylori SS1 \\
\hline \multirow{4}{*}{ Hesperetin } & 2.5 & - & - & - \\
& 5 & +++ & +++ & +++ \\
& 10 & +++ & +++ & +++ \\
Hesperidin & 20 & +++ & +++ & +++ \\
& 2.5 & - & - & - \\
& 5 & - & - & - \\
& 10 & - & - & - \\
Genkwanin & 20 & - & - & - \\
& 2.5 & - & - & - \\
& 5 & - & - & - \\
& 10 & - & - & - \\
\hline \multirow{3}{*}{ 7-O-Butylnaringenin } & 20 & - & - & - \\
& 2.5 & - & - & + \\
& 5 & - & ++ & + \\
\hline
\end{tabular}

-: No inhibition $(\leq 8.9 \mathrm{~mm})$; +: Slight inhibition $(9.0-14.9 \mathrm{~mm})$; ++: Moderate inhibition $(15-19.9 \mathrm{~mm})$; +++ : Strong inhibition $(\geq 20 \mathrm{~mm})$.

In addition, the antimicrobial effects of flavonoids were slightly different among the $H$. pylori strains tested.

\subsection{Evaluation of Antimicrobial Effects on H. pylori Strains}

The antimicrobial effects of naringenin, hesperetin, and 7-O-butylnaringenin against three $H$. pylori strains indicated that naringenin below $200 \mathrm{mM}$ was the least effective among the three flavonoids and the effect was not significantly different from with blank and control $(p>0.05$, Figure 2(A)).

Hesperetin has a stronger antimicrobial effect than naringenin against $H$. pylori, although the effect differed between the strains (Figure 2(B)). Hesperetin $(200 \mu \mathrm{M})$ showed stronger antimicrobial effects to $H$. pylori SS1 than other two strains and reduced the number by $2.5 \log$ colony forming units ( $p$ < 0.05). 7-O-Butylnaringenin at 100-200 $\mu \mathrm{M}$ showed a stronger antimicrobial effect than the other two flavonoids tested (Figure $2(\mathrm{C})$ ). The antimicrobial effect of 7-O-butylnaringenin was $>10$-fold of that of unmodified naringenin, and 7-O-butylnaringenin at $200 \mu \mathrm{M}$ was highly effective against $H$. pylori $51(p<0.05)$. The results indicated that 7-O-butylnaringenin was the most effective of all the flavonoids tested at any concentration. However, the effects of 7-O-butylnaringenin in the broth culture method were different from those in the disc diffusion method (Table 1). These observations are likely due to the differences in the diffusivity of flavonoids on agar culture and paper disc [22]. The inhibitory effects of flavonoids on the growth of microorganism can vary depending upon the type and size of molecular groups and the positions of their side chains on the flavonoid backbone structure [16,22]. Since many different assays are employed in flavonoid research, including the paper disk diffusion method, the agar dilution assay, the broth microdilution method, the results appear 
widely conflicting. In particular, assays depending on the diffusion of flavonoids may not give a reliable quantitative measure of antibacterial activity because a strong antibacterial flavonoid may have a low rate of diffusion [23].

Figure 2. The antimicrobial effects of three flavonoids on growth of $H$. pylori 26695, 51, and SS1. Initial cell density was adjusted to be $2.0 \times 10^{5} \mathrm{CFU} / \mathrm{mL}$. (A) naringenin, (B) hesperetin, and (C) 7-O-butylnaringenin.
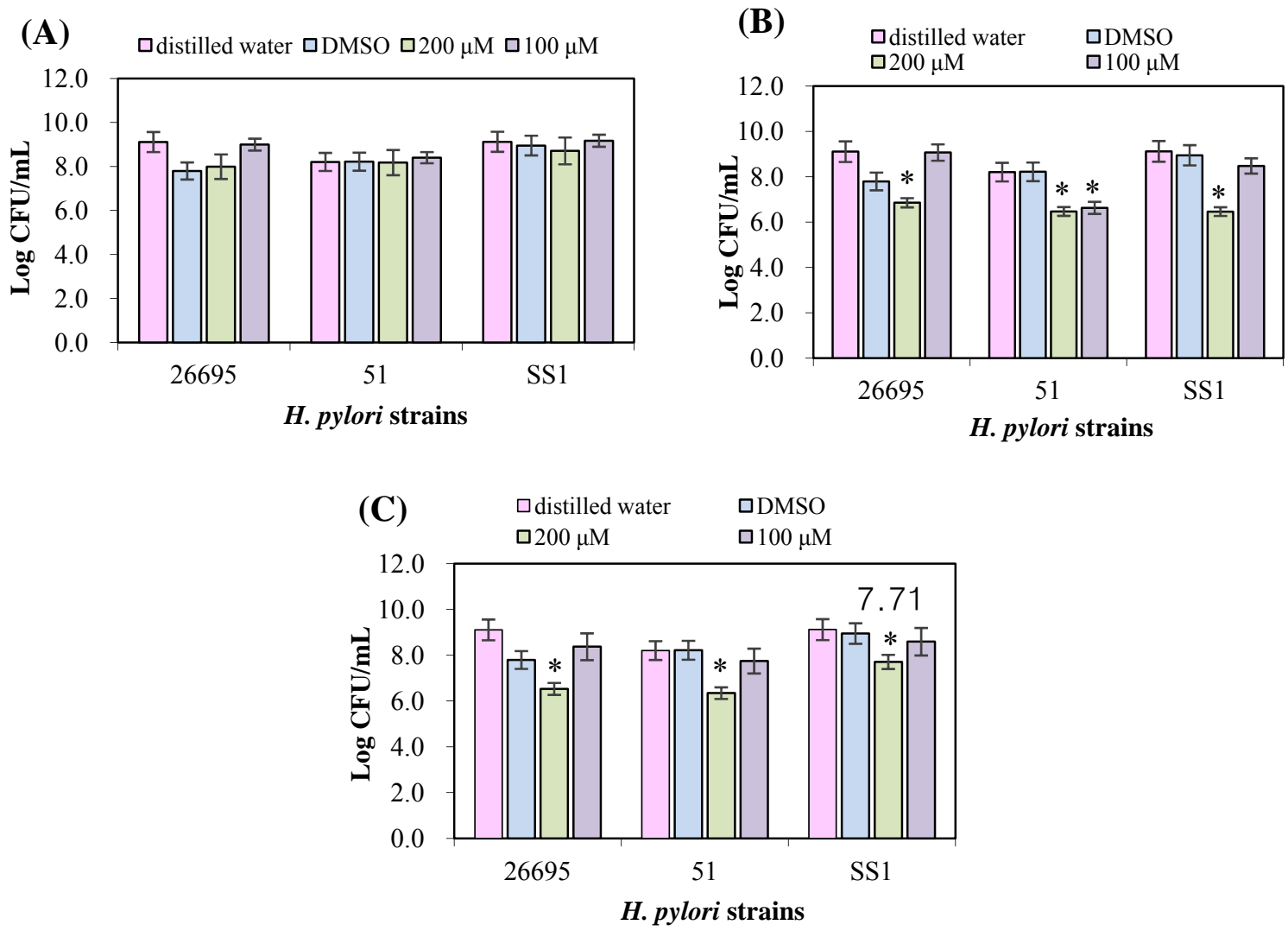

Values are mean with standard error. ${ }^{*} p<0.05$ compared with control.

\subsection{Urease Inhibition by Flavonoids in H. pylori}

The urease of $H$. pylori is known to be one of the major factors for its resistance to the strong acidic conditions of the stomach [1,7]. H. pylori urease produces ammonia from urea and raises the $\mathrm{pH}$ of the stomach. Since urea is a small uncharged molecule, it can passively diffuse through the membrane of ureolytic bacteria [2,7]. Naringenin had little effect on the urease activity at $<200 \mu \mathrm{M}$, while both hesperetin and 7-O-butylnaringenin had significant inhibitory effects on the urease activities of three $H$. pylori strains (Table 2). 7-O-Butylnaringenin has a stronger inhibitory effect on urease than the other two flavonoids, showing the highest inhibitory effect on $H$. pylori 26695, 51, and SS1 with the inhibition ratios of about $27 \%, 62 \%$, and $71 \%$ at $200 \mu \mathrm{M}$ concentration, respectively.

Paulo et al. [30] demonstrated that resveratrol and red wines showed an inhibitory effect on H. pylori urease activity, which is considered a virulence factor of this organism. Masuda et al. [13] reported that gochoonangi (Wasabia japonica) has urease inhibitory activity. They showed that the inhibition rates of roots $(44.6,45.8$, and $39.7 \%)$ and leaves $(36.7,40.2$, and $48.7 \%)$ on urease activities 
of H. pylori NCTC11637, YS27, and YS50, respectively. Although the anti-H.pylori activity of flavonoids has been described by several authors $[2,5,6,13,14,16,19,20]$, there has been little study on the inhibition of urease activity on $H$. pylori strains.

Table 2. The inhibitory effect (\%) of various flavonoids at $200 \mu \mathrm{M}$ on urease activity of H. pylori strains after incubation for $3 \mathrm{~h}$ at $37^{\circ} \mathrm{C}$.

\begin{tabular}{l|ccc}
\hline \multicolumn{1}{|c|}{ Flavonoids } & Naringenin & Hesperetin & 7-O-Butylnaringenin \\
\hline Strains & $1.33 \pm 0.13^{* \text {,ax }}$ & $0.93 \pm 0.15^{\text {ax }}$ & $27.49 \pm 0.32^{\text {bx }}$ \\
H. pylori 26695 & $16.55 \pm 1.23^{\text {ax }}$ & $7.31 \pm 0.23^{\text {ax }}$ & $61.93 \pm 1.45^{\text {by }}$ \\
H. pylori 51 & $13.64 \pm 0.98^{\text {ax }}$ & $6.32 \pm 0.11^{\text {ax }}$ & $70.75 \pm 3.56^{\text {by }}$ \\
H. pylori SS1 &
\end{tabular}

* Inhibition effect $(\%)=\left(\mathrm{OD}_{\text {control }}-\mathrm{OD}_{\text {sample }} / \mathrm{OD}_{\text {control }}\right) \times 100 ;{ }^{\mathrm{a}-\mathrm{b}}$ Different letters within a row differ significantly $(p<0.05) ;{ }^{\mathrm{x}-\mathrm{y}}$ Different letters within a column differ significantly $(p<0.05)$.

\subsection{Morphological Study of H. pylori Using SEM}

The treatment of $H$. pylori with flavonoids at $200 \mu \mathrm{M}$ resulted in morphological alterations of the membrane compared with the control (Figure 3). H. pylori cells in the control treatment had regular shapes and smooth surfaces (Figure 3(A)), but the cells treated with hesperetin (Figure 3(C)) and 7-O-butylnaringenin (Figure 3(D)) at $200 \mu \mathrm{M}$ were damaged and had irregular shapes and rough surfaces.

Figure 3. SEM micrographs of $H$. pylori 26695 treated with naringenin, hesperetin, and 7-O-butyl naringenin at $200 \mu \mathrm{M}$ concentration. (A) control, (B) naringenin, (C) hesperetin, and (D) 7-O-butylnaringenin.
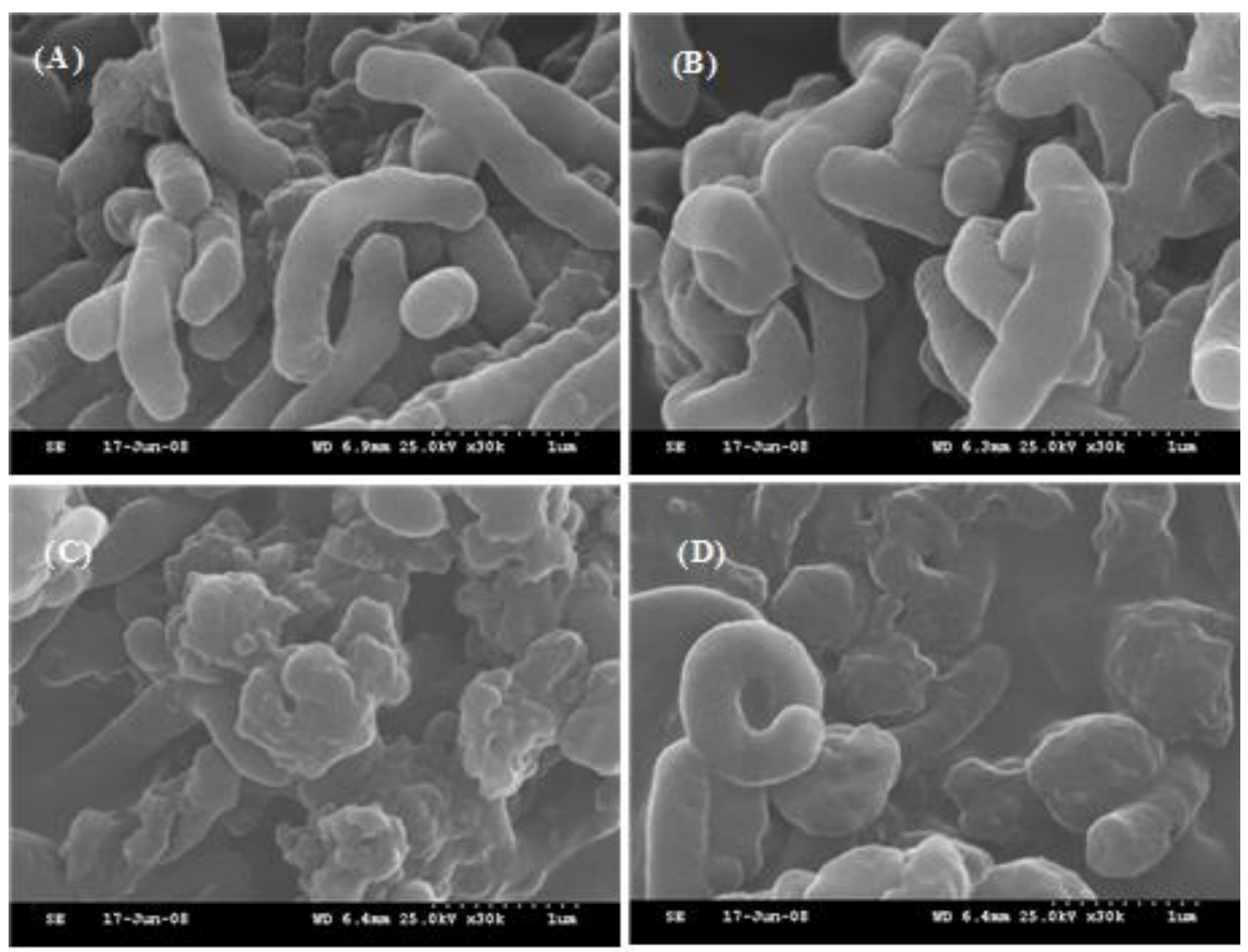
In addition, hesperetin and 7-O-butylnaringenin generated different cell damage patterns. Although the morphological changes in 7-O-butylnaringenin-treated cells were less pronounced than those with hesperetin-treated cells, 7-O-butylnaringenin reduced the viable cell count more and had a stronger inhibitory effect on urease activity than hesperetin (Figure 2 and Table 2). These results indicated that the mechanisms of cell damages may be quite different depending on the kind of flavonoids. On the other hand, naringenin at the same concentration did not cause detectable cell damages (Figure 3(B)).

The paper disc diffusion results indicated that the cells incubated with hesperetin and 7-O-butylnaringenin showed severe membrane damages with membrane integrity disruptions (Table 1). The initial exposure of hesperetin and 7-O-butylnaringenin to $H$. pylori caused large surface collapses in the cells and produced wrinkled abnormalities in the cells of $H$. pylori with numerous small clefts, regularly distributed on the bacterial cell surface. Such morphological features in bacterial cells may be due to the lysis of the outer membrane followed by the loss of cellular electron-dense materials on the surface of treated cells [31,32]. Although the mechanisms by which the effects observed in this study are not yet known, it likely involves with the perturbation or inhibition of metabolism such as nucleic acid synthesis, cytoplasmic membrane function, and energy metabolism [22].

\section{Conclusions}

In conclusion, the greater inhibitory effect of 7-O-butylnaringenin compared with natural naringenin may be helpful in investigating the antimicrobial effects of other flavonoids against $H$. pylori, and in the development of new drugs for patients with gastric diseases caused by $H$. pylori. In addition, 7-O-butylnaringenin can be chemically synthesized from orange or tangerine waste, increasing its industrial value as an antimicrobial agent.

\section{Acknowlegments}

This work was supported by Priority Research Centers Program through the National Research Foundation of Korea (NRF) funded by the Ministry of Education, Science and Technology (2012-0006686).

\section{Conflicts of Interest}

The authors declare no conflict of interest.

\section{References}

1. Marshall, B.J. Campylobacter pyloridis and gastritis. J. Infect. Dis. 1986, 153, 650-657.

2. Fukai, T.; Marumo, A.; Kaitou, K.; Kanda, T.; Terada, S.; Nomura, T. Anti-Helicobacter pylori flavonoids from licorice extract. Life Sci. 2002, 71, 1449-1463.

3. Jiang, X.; Doyle, M.P. Optimizing enrichment culture conditions for detecting Helicobacter pylori in foods. J. Food Prot. 2002, 65, 1949-1954.

4. Smith, J.L. The role of gastric acid in preventing foodborne disease and how bacteria overcome acid conditions. J. Food Prot. 2003, 66, 1292-1303. 
5. Stamatis, G.; Kyriazopoulos, P.; Golegou, S.; Basayiannis, A.; Skaltsas, S.; Skaltsa, H. In vitro anti-Helicobacter pylori activity of Greek herbal medicines. J. Ethnopharmacol. 2003, 88, 175-179.

6. Shin, J.E.; Kim, J.M.; Bae, E.A.; Hyun, Y.J.; Kim, D.H. In vitro inhibitory effects of flavonoids on growth, infection and vacuolation of Helicobacter pylori. Planta Med. 2005, 71, 197-201.

7. Stingel, K.; Reuse, H.D. Staying alive overdose: How does Helicobacter pylori control urease activity? Int. J. Med. Microbiol. 2005, 295, 307-315.

8. Hazell, S.L.; Lee, A. Campylobacter pyloridis, urease, hydrogen ion back diffusion and gastric ulcers. Lancet 1986, 5, 15-17.

9. Hazell, S.L.; Borody, T.J.; Lee, A. Campylobacter pyloridis gastritis. I: Detection of urease as a marker of bacterial colonization and gastritis. Am. J. Gastroenterol. 1987, 82, 292-296.

10. Muhammad, A.; Farooq, A.; Muhammad, R.J.; Muhammad, A.I.; Umer, R. Green synthesis of silver nanoparticles through reduction with Solanum xanthocarpum L. Berry extract: Characterization, antimicrobial and urease inhibitory activities against Helicobacter pylori. Int. J. Mol. Sci. 2012, 13, 9923-9941.

11. Jiang, X.; Doyle, M.P. Effect of environmental and substrate factors on survival and growth of Helicobacter pylori. J. Food Prot. 1998, 61, 929-933.

12. Nicoline, F.T.; Lucy, M.N.; Roland, N.N. DNA sequence analysis of South African Helicobacter pylori vacuolating cytotoxin gene (vacA). Int. J. Mol. Sci. 2011, 12, 7459-7468.

13. Masuda, H.; Naohide, K.; Woo, G.J.; Shin, I.S. Inhibitory effects of gochoonangi (Wasabia japonica) against Helicobacter pylori and its urease activity. Food Sci. Biotechnol. 2004, 13, 191-196.

14. Silvia, M.; Claudia, D.A.; Andrea, C.; Silvia, F.; Francesca, B.; Annalisa, S.; Natale, F.; Claudio, R. Antimicrobial activity against Helicobacter pylori strains and antioxidant properties of blackberry leaves (Rubus ulmifolius) and isolated compounds. Int. J. Antimicrob. Agric. 2009, $34,50-59$.

15. Muhammad, A.; Farooq, A.; Fauqia, N.; Tahir, M.; Nazamid, S. Anti-Helicobacter pylori and urease inhibition activities of some traditional medicinal plants. Molecules 2013, 18, 2135-2149.

16. Stojanovic, G.; Radulovic, N.; Hashimoto, T.; Palic, R. In vitro antimicrobial activity of extracts of four Achillea species: The composition of Achillea clavennae L. (Asteraceae) extract. J. Ethnopharmacol. 2005, 101, 185-190.

17. Maria, H.; Concepción, S.-M.; Sonia, P.T. Flavonoid-flavonoid interaction and its effect on their antioxidant activity. Food Chem. 2010, 121, 691-696.

18. Bang, M.H.; Jung, Y.J.; Kim, W.K. Effect of several flavonoids on cancer cell motility in human fibrosarcoma HT 1080 cells. Food Sci. Biotechnol. 2004, 13, 739-743.

19. Kim, K.T.; Moon, S.H.; Yeo, E.J.; Han, Y.S.; Nah, S.Y.; Paik, H.-D. Inhibitory effect of 7-O-butyl naringenin on growth of Helicobacter pylori ATCC 26695. Food Sci. Biotechnol. 2006, 15, 466-468.

20. Ghaleb, A.; Bassam, A.-S.; Kamel, A. Antibacterial activities of some plant extracts alone and in combination with different antimicrobials against multidrug-resistant Pseudomonas aeruginosa strains. Asian Pac. J. Trop. Med. 2010, 3, 266-269. 
21. Son, D.J.; Lee, S.E.; Park, B.S. Inhibitory effects of naturally occurring flavonoids on a human intestinal bacterium, Clostridium perfringens. Food Sci. Biotechnol. 2003, 12, 180-182.

22. Tim, C.T.P.; Lamb, A.J. Antimicrobial activity of flavonoids. Int. J. Antimicrob. Agric. 2005, 26, 343-356.

23. Tim, C.T.P.; Hamilton, V.E.S.; Lamb, A.J. Assessment of the antibacterial activity of selected flavonoids and consideration of discrepancies between previous reports. Microbial. Res. 2003, 158, 281-289.

24. Christy, E.M.L.; Clarke, A.M.; Munzhelele, T.; Ezekiel, G.; Noxolo, F.M.; Roland, N.N. Selected South African honeys and their extracts possess in vitro anti-Helicobacter pylori activity. Arch. Med. Res. 2010, 41, 324-331.

25. Yerra, K.R.; Lien, H.-M.; Lin, Y.H.; Hsu, Y.-M.; Yeh, C.-T.; Chen, C.C.; Lai, C.H.; Tzeng, Y.M. Antibacterial activities of Anisomeles indica constituents and their inhibition effect on Helicobacter pylori-induced inflammation in human gastric epithelial cells. Food Chem. 2012, 132, 780-787.

26. Kim, K.T.; Paik, H.-D. Propolis as a Multi-Functional Natural Material for Health. In Natural Products as Future Medicinal Agents; Hawthorne, S., Ed.; Transworld Research Network: Kerala, India, 2008; pp. 33-48.

27. Malekzadeh, F.; Ehsanifar, H.; Shahamat, M.; Levin, M.; Colwell, R.R. Antibacterial activity of black myrobalan (Terminalia chebulaetz) against Helicobacter pylori. Int. J. Antimicrob. Agric. 2001, 18, 85-88.

28. Mobley, H.L.T.; Cortesia, M.J.; Roseuthal, L.E.; Jones, B.D. Characterization of urease from Campylobacter pylori. J. Clin. Microbiol. 1988, 26, 831-836.

29. Tsugawa, H.; Suzuki, H.; Nakagawa, I.; Nishizawa, T.; Saito, Y.; Suematsu, M.; Hibi, T. Alpha-ketoglutarate oxidoreductase, an essential salvage enzyme of energy metabolism, in coccoid form of Helicobacter pylori. Biochem. Biophys. Res. Commun. 2008, 376, 46-51.

30. Paulo, L.; Oleastro, M.; Gallardo, E.; Queiroz, J.A.; Domi, F. Anti-Helicobacter pylori and urease inhibitory activities of resveratrol and red wine. Food Res. Int. 2011, 44, 964-969.

31. Becker-Ritta, A.B.; Martinelli, A.H.S.; Mitidierib, S.; Federa, V.; Wassermanna, G.E.; Santia, L.; Vainsteina, M.H.; Oliveirad, J.T.A.; Fiuzae, L.M.; Pasqualia, G.; et al. Antifungal activity of plant and bacterial ureases. Toxicon 2007, 50, 971-983.

32. Shin, S.Y.; Bajpai, V.K.; Kim, H.R.; Kang, S.C. Antibacterial activity of eicosapentaenoic acid (EPA) against foodborne and food spoilage microorganisms. LWT-Food Sci. Technol. 2007, 40, $1515-1519$.

(C) 2013 by the authors; licensee MDPI, Basel, Switzerland. This article is an open access article distributed under the terms and conditions of the Creative Commons Attribution license (http://creativecommons.org/licenses/by/3.0/). 